\title{
Analisis Peningkatan Kompetensi, Pelatihan, dan Motivasi \\ Terhadap Kinerja Karyawan \\ (Studi Pada Perusahaan Daerah Air Minum Surakarta)
}

\author{
Kukuh Purbo Marjiyanto ${ }^{(1)}$ \\ Zakky Fahma Auliya ${ }^{(2)}$ \\ Instititut Agama Islam Negeri Surakarta, Indonesia ${ }^{(1)(2)}$ \\ Kukuh.purbom@gmail.com ${ }^{(1)}$ \\ zakkyfahmaaulia@iain-surakarta.ac.id ${ }^{(2)}$
}

\begin{abstract}
This study aims to determine the effect of competence, training, and motivation on employee performance (a case study of a Surakarta municipal water company). This type of research is quantitative. This research uses primary data. The sample in this study were 112 respondents taken from Surakarta regional water company (PDAM) employees who had competence in their fields, and had received training and motivation from the company. The sampling technique uses simple purposive. Data collection method using a questionnaire. The results showed that competency had a significant effect on the performance as evidenced by the $t$ value of 4.381; a significance value of 0,000 <0.05. The training did not significantly influence the performance as evidenced by the $t$ value of 1.232; a significance value of 0.221>0.05. Motivation has a significant effect on the performance as evidenced by the t value of 3.074; significance value $0.003<0.05$.
\end{abstract}

Keywords: Competence; Training; Competence; Employee Performance

\section{ABSTRAK}

Penelitian ini bertujuan untuk mengetahui pengaruh kompetensi, pelatihan, dan motivasi terhadap kinerja karyawan (studi kasus Perusahaan Daerah Air Minum Surakarta). Jenis penelitian yang digunakan adalah kuantitatif. Penelitian ini menggunakan data primer. Sampel dalam penelitian ini sebanyak 112 responden yang diambil dari karyawan Perusahaan Daerah Air Minum (PDAM) Kota Surakarta yang memiliki kompetensi dalam bidangnya, serta telah mendapatkan pelatihan dan motivasi dari perusahaan. Teknik pengambilan sampel menggunakan purposive simple. Metode pengumpulan data dengan menggunakan kuesioner. Hasil penelitian menunjukkan bahwa kompetensi berpengaruh signifikan terhadap kinerja karyawan dibuktikan dari nilai t hitung sebesar 4,381; nilai signifikansi $0,000<0,05$. Pelatihan tidak berpengaruh signifikan terhadap kinerja karyawan dibuktikan dari nilai t hitung sebesar 1,232 ; nilai signifikansi $0,221>0,05$. Motivasi berpengaruh signifikan terhadap kinerja karyawan dibuktikan dari nilai t hitung sebesar 3,074; nilai signifikansi 0,003 <0,05.

Kata Kunci: Kompetensi; Pelatihan; Motivasi; dan Kinerja Karyawan 


\section{PEDAHULUAN}

Pengembangan SDM memang membutuhkan biaya yang cukup besar, tetapi biaya tersebut merupakan investasi jangka panjang bagi oraganisasi dibidang SDM. Karena SDM yang cakap dan terampil akan dapat bekerja efisien, efektif, pemborosan bahan baku dan ausnya mesin berkurang, hal tersebut akan membuka peluang bagi perusahaan untuk tumbuh dengan pesat, sehingga balas jasa terhadap karyawan wajar untuk ditingkatkan. Kemampuan karyawan baru yang digabung dengan program pengenalan dan pelatihan karyawan, kurang lebih akan menjamin hilangnya kesenjangan antara kemampuan kerja dan tuntutan kerja yang didasarkan untuk peningkatan produktifitas kerja perusahaan (Kasadirman, 2012; Widiari dan Darma, 2017)

Seperti yang diungkapkan Mulyani, bahwa "Pelatihan karyawan sangatlah penting bagi perusahaan, terutama dalam pengembangan karir sesuai dengan talenta karyawan, karena hal ini untuk menciptakan kandidat SDM yang unggul dan kompetitif" (Putra, 2016; Dewi dan Darma, 2017)

Berdasarkan penelitian dari Landa (2018) yang dilakukan di Lembaga Publik Tenaga Pasokan Air dan Pembuangan Limbah Perkotaan di Tanga, pelatihan yang dilakukan oleh perusahaan menjadi yang terbaik dari semua otoritas air perkotaan di Tanzania. Pelatihan dapat meningkatkan kinerja karyawan karena perusahaan membekali karyawannya pengetahuan dan keterampilan yang relevan. Peningkatkan kinerja karyawan menghasilkan pencapaian biaya penuh pada tahun 2013/2014, meningkatkan pendapatan dari 2,6 miliar pada tahun 2006/2007 hingga 8,9 miliar pada tahun 2014/2015, serta biaya pengeluaran non air turun dari $31 \%$ menjadi $21 \%$.

Pelatihan tidak akan memiliki pengaruh terhadap kinerja apabila proses dari kebutuhan pelatihan, perencanaan pelatihan, pelaksanaan pelatihan, dan penilaian pelatihan tidak dillaksanakan secara baik. Dari hasil penelitian menunjukan proses pendampingan karyawan yunior lebih dibutuhkan dibandingkan dengan pelatihan, hal ini karena mereka belum memiliki kepercayaan untuk meningkatkan kemampuan meskipun sudah diberikan pelatihan (Hok, Hubeis, \& Kuswanto, 2014)

Sumber daya manusia adalah suatu aset dari perusahaan, yang tingkat keberhasilan perusahaan ditentukan oleh kualitas para karyawan. Perusahaan akan mencapai optimal jika perusahaan mampu melihat kompetensi karyawan sesuai dengan kemampuan dimiliki oleh masing - masing karyawan. Pengembangan sumber daya dengan berbasis kompetensi akan membuat kinerja menjadi tinggi dan tentunya akan menguntungkan dari pihak perusahaan itu sendiri. Perencanaan tenaga karyawan yang bagus dapat ditentukan melalui upaya 
mengembangkan sumber daya manusia agar memiliki kompetensi yang unggul dalam bidangnya. Kompetensi tidak akan berpengaruh terhadap kinerja apabila sumber daya manusia yang dimiliki oleh perusahaan tingkat pendidikannya rendah dan tenaga kerjanya hanya para pekerja lapangan (Wakano, Pattiselanno, \& Kaplale, 2013)

Kemudian dalam penelitian yang dilakukan oleh Putra (2016) menunjukan bahwa kompetensi individu adalah faktor penting dalam mencapai kinerja karyawan, akan tetapi kompetensi harus mendapatkan respon yang baik dari pimpinan, sebab secara teori kinerja dengan kompetensi memiliki keterkaitan dan tidak dapat dipisahkan satu dengan yang lain. Dalam implementasinya perusahaan harus menempatkan karyawan sesuai dengan kompetensi yang dimiliki, karena karyawan yang bekerja di bidang sesuai dengan kompetensi akan mudah untuk bersinergi dalam memajukan pekerjaan.

Selain pelatihan dan kompetensi tak kalah pentingnya motivasi yang diberikan perusahaan terhadap karyawan. Motif atau dorongan sebagai kata kunci suatu motivasi akan muncul sebagai akibat dari pemenuhan kebutuhan yang tidak terpuaskan, dimana dorongan tersebut muncul secara alamiah atau dorongan dari dalam diri seseorang. Kebutuhan yang tidak terpuaskan dari seseorang berakibat pada situasi yang tidak menyenangkan. Situasi yang tidak menyenangkan akan mendorong seseorang untuk memenuhinya sehingga akan menimbulkan pemikiran yaitu didalam mencapai keinginan atau tujuan dibutuhkan tindakan. Sesuai dengan teori motivasi yang dikemukakan oleh Abraham A. Maslow yang mengatakan bahwa seseorang dimotivasi untuk memuaskan sejumlah yang melekat pada diri manusia yang cenderung bersifat bawaan (Hariandja, 2002)

Dari uraian diatas ada perbedaan hasil penelitian, terdapat gab diantara variabelvariabel dependent dengan independent yaitu antara variabel pelatihan dengan kinerja karyawan di dalam penelitiannya Landa (2018) menunjukan hubungan yang signifikan sedangkan penelitian dari Hok et al. (2014) menyatakan hubungan yang tidak signifikan.

Kemudian antara variabel kompetensi dengan kinerja karyawan di dalam penelitiannya Putra (2016) menunjukan hubungan yang signifikan sedangkan penelitian dari Wakano et al. (2013) menyatakan hubungan yang tidak signifikan. Dan juga antara variabel motivasi dengan kinerja karyawan di dalam penelitiannya Kusuma, Musadieq, \& Nurtjahjono (2015) menunjukan hubungan yang signifikan sedangkan penelitian dari Yuliana (2017) menyatakan hubungan yang tidak signifikan. 


\section{Kinerja}

Kinerja berasal dari kata Job Performance atau prestasi sesungguhnya yang dicapai oleh seseorang, kinerja adalah hasil kerja baik secara kualitas ataupun kuantitas yang dicapai oleh seorang karyawan sesuai dengan tanggung jawab yang diberikan. (Mangkunegara, 2013; Purnantara dan Darma, 2015).

Menurut Wirawan (2009), konsep kinerja merupakan kepanjangan dari kinetika energi kerja. Kinerja adalah luaran yang dihasilkan oleh fungsi-fungsi atau indikator-indikator suatu pekerjaan atau suatu profesi dalam waktu tertentu, kemudian kinerja juga merupakan hasil sinergi dari sejumlah faktor. Faktor-faktor tersebut adalah faktor lingkungan organisasi, faktor lingkungan eksternal dan faktor internal karyawan.

Riniwati (2011) menyatakan terkait tentang landasan nyata dari suatu perusahaan dalam berkinerja. Jika tidak ada kinerja, maka semua bagian perusahaan tidak akan mencapai tujuannya. Kinerja diperlukan untuk bahan evaluasi oleh pimpinan, kinerja juga merupakan catatan hasil yang dihasilkan oleh karyawan, dimana seseorang diminta untuk memainkan perannya dalam melaksanakan strategi perusahaan.

Untuk mendefinisikan kinerja dengan akurat, manager atau pimpinan harus memperhatikan beberapa unsur yaitu measures (ukuran), goal (sasaran), dan assessment (penilaian). Kinerja mempengaruhi seberapa besar karyawan berkontribusi di perusahaan, terdapat enam kriteria dasar dalam menilai kinerja yaitu kualitas, kuantitas, ketepatan waktu, dampak interpersonal, efektivitas biaya, dan kebutuhan untuk supervisi (Kaswan, 2011)

Kinerja karyawan berarti tindakan yang terkait dengan tugas yang diharapkan dari seorang karyawan dan bagaimana tindakan tersebut dilakukan, kemudian unsur-unsur yang meliputi kinerja karyawan meliputi kepuasan, kelesuan, motivasi, dan komitmennya terhadap pekerjaan, sedangkan pemenuhan fasilitas kerja karyawan menunjukkan kepuasan yang dirasakan oleh karyawan begitu dia berada di tempat kerja. (Iqbal \& Asrar-ul-haq, 2018)

Menurut Kasmir (2015) terdapat beberapa faktor yang mempengaruhi kinerja, antara lain:

1. Kemampuan dan keahlian, merupakan kemampuan atau skill yang dimiliki oleh sesorang di dalam melakukan suatu pekerjaan. Karyawan yang memiliki kemampuan yang baik akan menghasilkan kinerja yang baik, begitupun sebaliknya, karyawan yang tidak memiliki kemampuan yang baik maka kinerja yang dihasilkan tidak baik pula.

2. Pengetahuan, yaitu segala informasi yang berhubungan dengan pekerjaan yang sedang dikerjakan. Mengetahui pengetahuan tentang pekerjaan akan memudahkan karyawan dalam melakukan pekerjaannya begitu juga sebaliknya, karyawan yang kurang dalam 
pengetahuan pekerjaannya akan mengurangi hasil atau kualitas pekerjaan yang pada akhirnya akan mempengaruhi kinerjanya.

3. Rencana kerja, merupakan suatu rancangan pekerjaan untuk memudahkan karyawan dalam melakukan pekerjaannya. Artinya jika karyawan memiliki rancangan kerja yang baik maka dia dapat melakukan pekerjaannya dengan benar dan tepat, sebaliknya jika karyawan tidak memiliki rancangan kerja yang tidak baik, maka dia akan kesulitan dalam menyelesaikan pekerjaannya dengan cepat dan benar.

\section{Kompetensi}

Menurut Amstrong \& Baron (1998) kompetensi adalah dimensi perilaku yang ada dibelakang kinerja yang menunjukan bagaimana orang berperilaku ketika mereka menjalankan perannya dengan baik. Mc.Lelland dalam Moeheriono (2012) berpendapat bahwa kompetensi merupakan karakteristik dasar personel yang menjadi faktor penentu sukses tidaknya seseorang dalam mengerjakan suatu pekerjaan atau pada situasi tertentu. Kemudian Hutapea \& Thoha (2008) juga menjelaskan bahwa kompetensi itu adalah gambaran tentang apa yang harus diketahui atau dilakukan seseorang agar dapat melaksanakan pekerjaannya dengan baik.

Carter \& Gray (2011) mengemukakan bahwa individual competence describes what a person is capable of doing and includes a combination of motives and traits, the self-image of a person and his or her social role, skills and knowledge. Dari pendapat tersebut, nampak bahwa kompetensi individual dapat dilihat dari kemampuan seseorang untuk melakukan sesuatu pekerjaan dan termasuk didalamnya kombinasi motivasi dan sifatnya, citra diri atau peran sosialnya, keahlian dan pengetahuan.

Menurut Werner \& Weckenmann (2012) Pandangan untuk menganggap pengembangan kompetensi sebagai tugas individu karyawan, didasarkan pada paradigma tradisional untuk meningkatkan kinerja secara mantap dengan pengalaman yang berkembang. Diasumsikan bahwa seorang karyawan telah mencapai semua keterampilan dan pengetahuan yang diperlukan untuk melakukan tugas yang diberikan, dicapai dalam pendidikan kejuruan dasar untuk profesi yang dipertimbangkan yang mencakup pendidikan di sekolah dan magang. Aplikasi pada masalah yang diberikan dan dengan demikian solusinya dipandang tergantung terutama pada kemauan dan bakat dasar karyawan. Dengan meningkatnya pengalaman, keterampilan dasar yang tersedia akan diasah dan kinerja akan menjadi lebih efisien dan lancar

Menurut Boulter, M. Dalziel., \& Hill (1996) level kompetensi adalah sebagai berikut: skill, knowledge, social role, self image, trait dan motive. Skill adalah kemampuan untuk melaksanakan suatu tugas dengan baik. Knowledge adalah suatu keadaan dimana seseorang 
memiliki informasi dalam bidang tertentu. Social role adalah sikap maupun nilai yang dimiliki oleh seseorang kemudia ditonjolkan dalam masyarakat (ekspresi nilai-nilai diri). Self image adalah suatu pandangan seseorang terhadap diri sendiri. Trait adalah karakteristik abadi yang dimiliki oleh seseorang yang membuat orang tersebut berperilaku dalam masyarakat. Motive adalah sesuatu dorongan seseorang yang secara konsisten berperilaku karena perilaku tersebut dianggap sebagai sumber kenyamannya.

Menurut (Kartika \& Sugiarto, 2014) pengertian kompetensi dalam kenyataannya belum ada kesepakatan universal dan beberapa pakar memberikan pengertian yang cukup bervariasi. Namun secara umum istilah kompetensi sumber daya manusia dapat disimpulkan sebagai capability to perform yaitu kemampuan yang mengacu pada kemampuan karyawan untuk melakukan pekerjaan yang diharapkan dengan standar yang disyaratkan.

Kemudian Sanches (1997) menegaskan bahwa kompetensi dapat dibedakan menjadi dua, yaitu yang bersifat visible, seperti kompetensi pengetahuan (knowledge competency) dan kompetensi keahlian (skill competency) serta kompetensi yang bersifat invisible (hidden competency), contoh konsep diri, sifat maupun motif kemudian dapat dikategorikan dalam variabel sikap (attitude).

\section{Pelatihan}

Menurut Mondy (2008) Pelatihan adalah jantung dari upaya berkelanjutan untuk meningkatkan kompetensi karyawan dan kinerja organisasi. Sedangkan menurut Dessler (2010) pelatihan adalah proses mengajar keterampilan yang dibutuhkan karyawan baru untuk melakukan pekerjaannya. Kemudian menurut Rivai Veithzal (2013) pelatihan merupakan upaya untuk meningkatkan kualitas sumber daya manusia, pelatihan membantu karyawan dalam memahami suatu pengetahuan praktis dan penerapannya, guna meningkatkan keterampilan, kecakapan, dan upaya maupun sikap yang perlu dilakukan organisasi dalam usaha mencapai tujuan

Menurut Kasmir (2016) pelatihan merupakan proses untuk membentuk dan membekali karyawan dengan menambah keahlian, pengetahuan, kemampuan, dan perilakunya. Artinya pelatihan akan membentuk perilaku karyawan sesuai dengan harapan dari perubahan, misalnya sesuai dengan budaya perusahaan. Begitu juga menurut Yao, Liu, \& Cui (2019) pelatihan yang dirancang dengan baik akan membantu individu dalam mengembangkan keterampilannya.

Handoko (2014) mengemukakan bahwa prinsip pelatihan dapat digunakan sebagai pedoman untuk pelatihan kepada karyawan agar berjalan lebih efektif, prinsip-prinsip belajar 
yang ada dalam pelatihan meliputi program pelatihan yang memiliki sifat partisipatif, relevan, pengulangan (repetisi) dan pemindahan, serta mampu memberi umpan balik mengenai kemajuan para peserta latihan tersebut. Latihan akan semakin efektif apabila prinsip-prinsip tersebut sudah terpenuhi.

Menurut Mangkunegara (2013) menyatakan bahwa materi pelatihan harus disesuaikan dengan tujuan yang hendak dicapai, materi harus diberikan secara sistematis dan berdasarkan tahapan-tahapan. Sedangkan (Marwansyah, 2012) menjelaskan bahwa materi pelatihan yang baik harus selalu diperbarui sesuai dengan kondisi yang ada supaya isi (content) pelatihan benar-benar sesuai dengan kebutuhan dan kemampuan peserta.

Triasmoko \& Mukzam (2014) menyimpulkan bahwa pemilihan materi untuk pelatihan harus memperhatikan dari kesesuaian pekerjaan, pendidikan, kondisi pelatihan, ketentuan alokasi waktu pelatihan dan isi materi pelatihan harus diperbarui sehingga tujuan pelatihan dapat tercapai.

Menurut Marwansyah (2012) Ada beberapa metode pelatihan yang dipilih hendaknya disesuaikan dengan jenis pelatihan yang akan dilaksanakan, berikut ini adalah berbagai teknik melatih yang sudah umum dikenal dan digunakan dewasa ini yaitu metode on the job training meliputi pelatihan dalam jabatan, sistem rotasi pekerjaan, magang, serta metode off job training meliputi sistem ceramah, simulasi, dan belajar sendiri.

Menurut Handoko (2014) terdapat kriteria yang dapat digunakan untuk mengukur pelatihan kerja yaitu fasilitas kerja yang diukur dengan melihat kelengkapan fasilitas yang digunakan dalam kegiatan pelatihan dan penggunaan fasilitas pelatihan, kemudian dari kemampuan peserta yang dilihat dari seberapa pengetahuan dan ketrampilan yang dimiliki para karyawan, dari metodenya dapat diukur dengan melihat kelengkapan fasilitas yang digunakan dalam kegiatan pelatihan dan penggunaan fasilitas pelatihan, dari kemampuan pelatih dengan melihat kemampuan dan pengetahuan pelatih program pelatihan harus benar-benar menguasai materi baik secara teori maupun praktek, serta dari materi pelatihan dengan ditinjau melihat apa yang akan di kembangkan oleh peserta pelatihan dengan memaparkan materi yang mudah dipahami peserta pelatihan lainnya.

\section{Motivasi}

Menurut Morgan (1986) motivasi diartikan sebagai "untuk mendorong dan menekan dengan kuat" yang akan muncul dalam perilaku yang gigih dalam mengarah pada pencapaian tujuan-tujuan tertentu. Sedangkan menurut Robbins (1998) motivasi adalah kesediaan untuk 
mengeluarkan tingkat upaya yang tinggi untuk tujuan organisasi, yang dikondisikan oleh kemampuan upaya itu dalam memenuhi beberapa kebutuhan individu.

Menurut Ermiyanto (2017) motivasi merupakan daya pendorong yang mengakibatkan karyawan mau dan rela mengerahkan kemampuan dalam bentuk keahlian atau ketrampilan, tenaga, dan waktunya untuk menyelesaikan berbagai kegiatan yang menjadi tanggung jawabnya serta melaksanakan kewajibannya untuk mencapai suatu tujuan dan berbagai target perusahaan yang telah ditentukan sebelumnya (didukung juga penelitian oleh Widiatmika dan Darma, 2018).

Menurut Notoatmodjo (2014) teori motivasi dua faktor Herzberg (Herzberg's Two Factors Motivation Theory) menyatakan bahwa faktor-faktor penyebab kepuasan (satisfier) yang disebut juga faktor motivasional merupakan faktor pendorong yang ada dalam diri seseorang untuk berprestasi (kondisi intrinsik), sedangkan faktor penyebab ketidakpuasan (dissatisfier) yang disebut juga faktor higiene menyangkut kebutuhan akan pemeliharaan atau maintenance factor merupakan faktor pendorong yang ada dalam diri seseorang untuk berprestasi yang bersumber dari luar diri orang tersebut, seperti dari organisasi tempat orang tersebut bekerja (kondisi ekstrinsik).

Menurut Siagian (2010) motivasi instrinsik bersumber dari dalam individu. Motivasi ini menghasilkan integritas dari tujuan yang ingin dicapai sehingga menimbulkan kepuasan yang ada dalam diri individu. Kemudian menurut Hasibuan (2014) motivasi intrinsik adalah motif-motif yang menjadi aktif atau berfungsinya tidak perlu dirangsang dari luar, karena dalam diri setiap individu sudah ada dorongan untuk melakukan sesuatu, ada beberapa faktor dari motivasi intrinsik, antara lain: tanggung jawab, pekerjaan itu sendiri, penghargaan, serta pengembangan dan kemajuan.

Abraham Maslow $(1943 ; 1970)$ menyatakan bahwa setiap manusia pasti memiliki kebutuhan pokok. Manusia menunjukkan kebutuhannya yang dibentuk dalam 5 tingkatan yang berbentuk piramid, yang dimulai dari dorongan tingkatan terbawah. Lima tingkat kebutuhan dapat juga dikenal dengan nama Hirarki Kebutuhan Maslow, dimulai dari kebutuhan biologis dasar sampai motif psikologis yang lebih kompleks yang akan dianggap penting setelah kebutuhan dasar terpenuhi.

Kebutuhan pada suatu peringkat paling tidak harus terpenuhi sebagian sebelum kebutuhan pada peringkat berikutnya menjadi penentu tindakan yang penting: (Widayat Prihartanta, 2015) 


\section{METODE PENELITIAN}

\section{Jenis Penelitian}

Jenis penelitian ini menggunakan metode penelitian kuantitatif. Penelitian kuantitatif yaitu metode penelitian yang hasil penelitiannya berupa angka-angka statistic (Sugiyono, 2012). Penelitian ini dimaksudkan untuk mengetahui faktor-faktor yang mempengaruhi kinerja karyawan Perusahaan Daerah Air Minum (PDAM) Kota Surakarta. Dalam penelitian ini kompetensi, pelatihan, dan motivasi dijadikan sebagai faktor-faktor yang kemungkinan besar dapat mempengaruhi kinerja karyawan Perusahaan Daerah Air Minum (PDAM) Kota Surakarta.

\section{Objek Penelitian}

Dalam penelitian ini, populasinya adalah karyawan PDAM Kota Surakarta yang memiliki kompetensi dibidangnya serta telah mendapatkan pelatihan dan motivasi di perusahaan. Kemudian yang menjadi responden adalah karyawan dengan usia 17 tahun hingga 55 tahun yang memiliki kompetensi dibidangnya serta telah mendapatkan pelatihan dan motivasi di perusahaan.

Kuesioner disebarkan secara langsung kepada responden yang memiliki kompetensi dibidangnya serta telah mendapatkan pelatihan dan motivasi di perusahaan. Dari data yang terkumpul akan diidentifikasi berdasarkan Jenis Kelamin, Usia, Pendidikan, dan Lama Bekerja. Identifikasi ini dilakukan untuk mengetahui secara umum gambaran dari responden dalam penelitian ini.

\section{Teknik Pengumpulan Data}

Penelitian ini menggunakan metode kuesioner atau angket. Penelitian ini menggunakan kuesioner lalu dibagikan kepada karyawan Perusahaan Daerah Air Minum (PDAM) Kota Surakarta yang menguasai pekerjaan dalam bidangnya serta telah mendapatkan pelatihan dan motivasi dari perusahaan. Untuk mengukur pendapat responden digunakan Skala Ordinal, dengan menggunakan rentang angka dari angka 1 untuk jawaban responden sangat tidak setuju sampai dengan angka 5 untuk jawaban responden sangat setuju.

Jumlah total kuesioner yang disebar langsung ke lapangan adalah 130 kuesioner tetapi kuesioner yang digunakan dalam penelitian ini adalah 112 kuesioner. Jadi ada 18 kuesioner yang tidak dipakai, hal ini dikarenakan pada saat pengisian kuesioner, responden kurang teliti sehingga ada kuesioner yang tidak terisi secara lengkap. 


\section{Analisis Data}

\section{Uji Ketepatan Model}

\section{Uji Koefisien Determinasi (Uji Adjusted $R^{2}$ )}

\section{Uji F}

Uji ini bertujuan untuk mengetahui model penelitian dapat dikatakan fit atau tidak. Uji F dapat dilakukan dengan melihat tingkat signifikansi $\alpha=0,05$ dan kriteria pengambilan keputusan yaitu dengan membandingkan nilai $\mathrm{f}$ hitung dan $\mathrm{f}$ tabel, apabila Fhitung $>$ Ftabel maka seluruh variabel independen berpengaruh terhadap variabel dependen (Ghozali, 2013)

\section{Analisis Regresi Linier Berganda}

Teknik analisis regresi linier berganda digunakan untuk mengetahui pengaruh kompetensi, pelatihan dan motivasi terhadap kinerja karyawan PDAM Surakarta. Adapun persamaan umum regresi berganda yang digunakan adalah sebagai berikut :

$\mathrm{Y}=\mathrm{a}+\mathrm{b} 1 \mathrm{X} 1+\mathrm{b} 2 \mathrm{X} 2+\mathrm{b} 3 \mathrm{X} 3+\mathrm{e}$

Dimana :

$\mathrm{Y}=$ Kinerja Karyawan

$\mathrm{a}=$ Konstanta

b1, b2, b3 = Koefisien regresi parsial

$\mathrm{X} 1=$ Variabel kompetensi

$\mathrm{X} 2$ = Variabel pelatihan

$\mathrm{X} 3$ = Variabel motivasi

$\mathrm{e}=$ Eror

\section{Uji Hipotesis (Uji statistik t)}

Uji hipotesis bertujuan untuk mengetahui signifikan atau tidaknya suatu variabel independen terhadap variabel dependen.Uji Signifikansi Parameter Individual (Uji statistik t) menunjukkan seberapa jauh pengaruh satu variabel independen secara individual dalam menerangkan variabel dependen. Hasil uji t dapat dilihat melalui tabel coefficients pada kolom sig. Dapat dikatakan terdapat pengaruh antara variabel bebas dengan variabel terikat secara parsial apabila probabilitas nilai signifikasinya $<0,05$. Dan dapat dikatakan tidak terdapat pengaruh yang signifikan antara masing-masing variabel bebas dan variabel terikat apabila probabilitas nilai signifikasinya $>0,05$. Hasil uji $\mathrm{t}$ juga dapat dilihat jika $\mathrm{t}$ hitung $>\mathrm{t}$ tabel, artinya suatu variabel secara individual atau parsial mempengaruhi variabel dependen (Ghozali, 2013) 


\section{HASIL DAN PEMBAHASAN}

\section{Hasil Penelitian}

Dalam penelitian ini, populasinya adalah karyawan PDAM Kota Surakarta yang memiliki kompetensi dibidangnya serta telah mendapatkan pelatihan dan motivasi di perusahaan. Kemudian yang menjadi responden adalah karyawan dengan usia 17 tahun hingga 55 tahun yang memiliki kompetensi dibidangnya serta telah mendapatkan pelatihan dan motivasi di perusahaan.

Kuesioner disebarkan secara langsung kepada responden yang memiliki kompetensi dibidangnya serta telah mendapatkan pelatihan dan motivasi di perusahaan. Dari data yang terkumpul akan diidentifikasi berdasarkan Jenis Kelamin, Usia, Pendidikan, dan Lama Bekerja. Identifikasi ini dilakukan untuk mengetahui secara umum gambaran dari responden dalam penelitian ini.

Jumlah total kuesioner yang disebar langsung ke lapangan adalah 130 kuesioner tetapi kuesioner yang digunakan dalam penelitian ini adalah 112 kuesioner. Jadi ada 18 kuesioner yang tidak dipakai, hal ini dikarenakan pada saat pengisian kuesioner, responden kurang teliti sehingga ada kuesioner yang tidak terisi secara lengkap.

\section{Analisis Deskriptif}

\section{Tabel 1}

Deskripsi Jawaban Responden terhadap Variabel Kompetensi (X1)

\begin{tabular}{|c|c|c|c|}
\hline Dimensi & Indikator & $\begin{array}{c}\text { Rata-Rata } \\
\text { Indikator }\end{array}$ & $\begin{array}{c}\text { Rata-Rata } \\
\text { Dimensi }\end{array}$ \\
\hline Motif & $\begin{array}{c}\text { Kemampuan mencapai } \\
\text { target }\end{array}$ & 4,2 & \multirow{2}{*}{4,28} \\
\hline Pengetahuan & $\begin{array}{c}\text { Penguasaan bidang } \\
\text { pengetahuan dalam } \\
\text { bidangnya }\end{array}$ & 4,33 & \\
\hline Keterampilan & $\begin{array}{c}\text { Mempunyai inovasi } \\
\text { dalam pekerjaan }\end{array}$ & 4,30 & \\
\hline
\end{tabular}


Tabel 2

Deskripsi Jawaban Responden terhadap Variabel Pelatihan (X2)

\begin{tabular}{|c|c|c|c|}
\hline Dimensi & Indikator & $\begin{array}{l}\text { Rata-Rata } \\
\text { Indikator }\end{array}$ & $\begin{array}{c}\text { Rata-Rata } \\
\text { Dimensi }\end{array}$ \\
\hline $\begin{array}{c}\text { Kesesuaian } \\
\text { materi pelatihan }\end{array}$ & $\begin{array}{c}\text { Kesesuaian materi } \\
\text { dengan penunjangan } \\
\text { penyelesaian } \\
\text { masalah dalam } \\
\text { pekerjaan }\end{array}$ & 4,32 & \multirow{3}{*}{4,34} \\
\hline \multirow[b]{2}{*}{$\begin{array}{l}\text { Peserta } \\
\text { pelatihan }\end{array}$} & $\begin{array}{c}\text { Peningkatan keahlian } \\
\text { kerja }\end{array}$ & 4,34 & \\
\hline & $\begin{array}{c}\text { Pengembangan } \\
\text { kemampuan dalam } \\
\text { menyelesaikan } \\
\text { pekerjaan }\end{array}$ & 4,36 & \\
\hline
\end{tabular}

Tabel 3

Deskripsi Jawaban Responden terhadap Variabel Motivasi (X3)

\begin{tabular}{|c|c|c|c|}
\hline Dimensi & Indikator & $\begin{array}{l}\text { Rata-Rata } \\
\text { Indikator }\end{array}$ & $\begin{array}{c}\text { Rata-Rata } \\
\text { Dimensi }\end{array}$ \\
\hline Arah perilaku & $\begin{array}{c}\text { Keinginan untuk } \\
\text { menyelesaikan } \\
\text { pekerjaan }\end{array}$ & 4,25 & \multirow{5}{*}{4,32} \\
\hline \multirow[b]{2}{*}{ Tingkat usaha } & $\begin{array}{l}\text { Keinginan bekerja lebih } \\
\text { baik dari sebelumnya }\end{array}$ & 4,38 & \\
\hline & $\begin{array}{l}\text { Keinginan gigih dalam } \\
\text { bekerja meski } \\
\text { lingungan kerja kurang } \\
\text { mendukung }\end{array}$ & 4,37 & \\
\hline \multirow{2}{*}{$\begin{array}{l}\text { Tingkat } \\
\text { kegigihan }\end{array}$} & $\begin{array}{c}\text { Keinginan } \\
\text { mengembangkan } \\
\text { keahlian untuk } \\
\text { memajukan perusahaan }\end{array}$ & 4,27 & \\
\hline & $\begin{array}{l}\text { Keinginan gigih dalam } \\
\text { bekerja meski } \\
\text { lingungan kerja kurang } \\
\text { mendukung }\end{array}$ & 4,31 & \\
\hline
\end{tabular}




\section{Tabel 4}

Deskripsi Jawaban Responden terhadap Variabel Kinerja (Y)

\begin{tabular}{|c|c|c|c|}
\hline Dimensi & Indikator & $\begin{array}{l}\text { Rata-Rata } \\
\text { Indikator }\end{array}$ & $\begin{array}{c}\text { Rata-Rata } \\
\text { Dimensi }\end{array}$ \\
\hline Kualitas & $\begin{array}{c}\text { Kemampuan } \\
\text { menyelesaikan tugas }\end{array}$ & 4,3 & \multirow{5}{*}{4,19} \\
\hline Kuantitas & $\begin{array}{c}\text { Kecepatan dalam } \\
\text { menyelesaikan tugas }\end{array}$ & 4,19 & \\
\hline $\begin{array}{l}\text { Tanggung } \\
\text { jawab }\end{array}$ & $\begin{array}{c}\text { Mampu menyelesaikan } \\
\text { tugas tanpa bantuan } \\
\text { atasan }\end{array}$ & 4,02 & \\
\hline Disiplin & $\begin{array}{c}\text { Ketaatan dalam aturan } \\
\text { perusahaan }\end{array}$ & 4,25 & \\
\hline $\begin{array}{l}\text { Pemhetahuan } \\
\text { mengenai } \\
\text { pekerjaan }\end{array}$ & $\begin{array}{l}\text { Pemahaman terhadap } \\
\text { prosedur kerja }\end{array}$ & 4,23 & \\
\hline
\end{tabular}

Tabel 4

Hasil Uji Koefisien Determinasi (Adjusted R Square)

Model Summary ${ }^{b}$

\begin{tabular}{|c|c|c|c|c|c|c|}
\hline \multirow[b]{2}{*}{ Model } & \multirow[b]{2}{*}{$\mathrm{R}$} & \multirow{2}{*}{$\begin{array}{c}\mathrm{R} \\
\text { Square }\end{array}$} & \multirow{2}{*}{$\begin{array}{l}\text { Adjusted } \\
\text { R Square }\end{array}$} & \multirow{2}{*}{$\begin{array}{l}\text { Std. Error of } \\
\text { the Estimate }\end{array}$} & \multicolumn{2}{|c|}{ Change Statistics } \\
\hline & & & & & $\begin{array}{c}\text { R Square } \\
\text { Change }\end{array}$ & F Change \\
\hline 1 &, $645^{\mathrm{a}}$ & ,416 & ,399 & 1,625 &, 416 & 25,604 \\
\hline
\end{tabular}

a. Predictors: (Constant), MOTIVASI, KOMPETENSI, PELATIHAN

b. Dependent Variable: KINERJA KARYAWAN

Sumber : Data Primer, diolah 2020

Dari tabel diatas dapat diketahui besarnya nilai adjusted $r$ square adalah 0,399 hal ini berarti variasi variabel kinerja karyawan dapat dijelaskan oleh variabel independen (kompetensi, pelatihan dan motivasi) sebesar 39,9\%. Sedangkan 60,1\% $(100 \%-39,9 \%=60,1 \%)$ dijelaskan oleh faktor-faktor lain yang tidak disertakan dalam model penelitian ini. 
Tabel 5

Hasil Uji Statistik t

Coefficients $^{\mathbf{a}}$

\begin{tabular}{|cc|c|c|c|c|c|}
\hline \multirow{2}{*}{ Model } & \multicolumn{2}{|c|}{$\begin{array}{c}\text { Unstandardized } \\
\text { Coefficients }\end{array}$} & $\begin{array}{c}\text { Standardized } \\
\text { Coefficients }\end{array}$ & \multirow{2}{*}{$\mathrm{t}$} & \multirow{2}{*}{ Sig. } \\
\cline { 2 - 5 } & $\mathrm{B}$ & Std. Error & Beta & & \\
\hline 1 & (Constant) & 4,638 & 2,038 & & 2,276 &, 025 \\
& KOMPETENSI &, 565 &, 129 &, 401 & 4,381 &, 000 \\
\hline & PELATIHAN &, 175 &, 142 &, 114 & 1,232 &, 221 \\
& MOTIVASI &, 315 &, 102 &, 263 & 3,074 &, 003 \\
\hline
\end{tabular}

a. Dependent Variable: KINERJA KARYAWAN

Sumber : Data Primer, diolah 2020

Berdasarkan tabel 5 mengenai hasil uji $\mathrm{t}$ di atas dapat diketahui sebagai berikut:

Hasil probabilitas signifikansi variabel kompetensi (X1) sebesar 0,000. Sehingga signifikansi sebesar $0,000<0,05$. Maka dapat disimpulkan bahwa variabel kompetensi berpengaruh terhadap kinerja karyawan.

Hasil probabilitas signifikansi variabel pelatihan (X2) sebesar 0,221. Sehingga signifikansi sebesar 0,221 >0,05. Maka dapat disimpulkan bahwa variabel pelatihan tidak berpengaruh terhadap kinerja karyawan.

Hasil probabilitas signifikansi variabel motivasi (X3) sebesar 0,003. Sehingga signifikansi sebesar $0,003<0,05$. Maka dapat disimpulkan bahwa variabel motivasi berpengaruh terhadap kinerja karyawan.

\section{Pembahasan}

\section{Pengaruh Kompetensi Terhadap Kinerja Karyawan}

Kompetensi berpengaruh signifikan terhadap Kinerja Karyawan Perusahaan Daerah Air Minum (PDAM) Kota Surakarta. Hal ini dinyatakan berdasarkan hasil signifikansi sebesar $0,000<0,05$. Sehingga dapat disimpulkan bahwa kompetensi berpengaruh signifikan terhadap kinerja karyawan Perusahaan Daerah Air Minum (PDAM) Kota Surakarta (H1 diterima dan H0 ditolak). Dalam penelitian ini, kompetensi dengan indikator kemampuan mencapai target, penguasaan pengetahuan dalam bidang, dan kemampuan menggunakan peralatan kerja dengan baik berpengaruh terhadap kinerja karyawan Perusahaan Daerah Air Minum (PDAM) Kota Surakarta. 
Hal ini mengindikasikan bahwa kompetensi cenderung membuat kinerja karyawan meningkat, dikarenakan karyawan memiliki kemampuan dalam mencapai target yang diberikan, menguasai pengetahuan didalam bidang pekerjaannya, dan mampu mengoperasikan peralatan kerja sesuai dengan SOP perusahaan.

Hasil penelitian ini didukung penelitian yang dilakukan oleh (Mubarok, 2018) yang menunjukkan bahwa kompetensi berpengaruh positif dan signifikan terhadap kinerja karyawan Badan Jaminan Sosial di Banten. Sejalan dengan penelitian yang dilakukan oleh (Dewi \& Ariyanto, 2016) menyatakan bahwa kompetensi berpengaruh signifikan terhadap kinerja karyawan, hasil penelitiannya yaitu memberikan gambaran kepada Group CTO Office untuk memfokuskan pengembangan kompetensi karena kompetensi memiliki pengaruh yang besar terhadap kinerja karyawan, peningkatan kinerja terlihat pada kemampuan penguasaan teknologi, keilmuan, dan penyelesaian masalah didalam tim, pelatihan soft skill dan hard skill juga memberikan kontribusi maksimal dalam kualitas kinerja

\section{Pengaruh Pelatihan Terhadap Kinerja Karyawan}

Pelatihan tidak berpengaruh signifikan terhadap kinerja karyawan Perusahaan Daerah Air Minum (PDAM) Kota Surakarta. Hal ini dinyatakan berdasarkan hasil signifikansi sebesar $0,221>0,05$.

Sehingga dapat disimpulkan bahwa pelatihan tidak berpengaruh signifikan terhadap kinerja karyawan Perusahaan Daerah Air Minum (PDAM) Kota Surakarta ( $\mathrm{H}_{2}$ ditolak dan $\mathrm{H} 0$ diterima). Pada penelitian ini, variabel pelatihan dengan indikator yang meliputi kesesuaian materi dengan penunjangan penyelesaian masalah, peningkatan keahlian kinerja melalui pelatihan, dan pengembangan kemampuan pelatihan karyawan berpengaruh terhadap kinerja karyawan Perusahaan Daerah Air Minum (PDAM) Kota Surakarta.

Perusahaan Daerah Air Minum (PDAM) Kota Surakarta memberikan fasilitas pelatihan dengan mengadakan seminar di bidang pekerjaan masing-masing, dimana dalam seminar tersebut tanpa memaksimalkan proses praktikum. Kesesuaian materi pelatihan dengan bidangnya, peningkatan keahlian kinerja, dan pengembangan pelatihan karyawan telah dilakukan oleh Perusahaan Daerah Air Minum (PDAM) Kota Surakarta, akan tetapi apabila tanpa pendampingan pekerjaan karyawan secara langsung maka pelatihan tidak akan berpengaruh terhadap kinerja karyawan karena peneliti mengamati bahwa sebagus apapun kinerja karyawan tetap membutuhkan bantuan atasan.. Tidak meratanya pelatihan juga merupakan hal yang sangat kuat pelatihan tidak berpengaruh signifikan terhadap kinerja 
karyawan Perusahaan Daerah Air Minum (PDAM) Kota Surakarta, sebab kesenjangan pendidikan antara karyawan lapangan dan kantor pusat sangat tinggi, sehingga pelatihan yang tidak merata berakibat pelatihan tidak tepat sasaran sesuai bidang yang dikuasai karyawan.

Hasil penelitian ini didukung penelitian yang dilakukan oleh (Hok et al., 2014) yang menyatakan bahwa pelatihan tidak berpengaruh positif terhadap kinerja karyawan perusahaan distributor alat berat. Dimana pelatihan tidak akan memiliki pengaruh terhadap kinerja apabila proses dari kebutuhan pelatihan, perencanaan pelatihan, pelaksanaan pelatihan, dan penilaian pelatihan tidak dilaksanakan secara baik. Dari hasil penelitian menunjukan proses pendampingan karyawan yunior lebih dibutuhkan dibandingkan dengan pelatihan, hal ini karena mereka belum memiliki kepercayaan untuk meningkatkan kemampuan meskipun sudah diberikan pelatihan.

Pengaruh Motivasi Terhadap Kinerja Karyawan Dari penelitian ini ditemukan bahwa motivasi berpengaruh signifikan terhadap kinerja karyawan Perusahaan Daerah Air Minum (PDAM) Kota Surakarta. Hal ini dinyatakan berdasarkan signifikansi variabel motivasi sebesar $0,003<0,05$. Sehingga dapat disimpulkan bahwa motivasi berpengaruh signifikan terhadap kinerja karyawan Perusahaan Daerah Air Minum (PDAM) Kota Surakarta (H3 diterima dan H0 ditolak). Dalam penelitian ini, variabel motivasi menggunakan variabel karyawan dapat menyelesaikan pekerjaan sesuai dengan jadwal yang diberikan, karyawan dapat bekerja lebih baik dari sebelumnya, karyawan akan mengembangkan keahlian untuk memajukan perusahaan, akan gigih dalam bekerja, dan akan serius dalam menyelesaikan pekerjaannya.

Jika karyawan telah memiliki motivasi untuk menyelesaikan pekerjaan sesuai dengan jadwal yang diberikan, dapat bekerja lebih baik dari sebelumnya, akan mengembangkan keahlian untuk memajukan perusahaan, akan gigih dalam bekerja, dan akan serius dalam menyelesaikan pekerjaannya, maka secara otomatis akan meningkatkan kinerja karyawan Perusahaan Daerah Air Minum (PDAM) Kota Surakarta, karena berbagai fasilitas baik tunjangan, bonus, dan non material berupa kenaikan jabatan karyawan yang berprestasi akan mendorong dan menggerakan motivasi dalam diri karyawan untuk memajukan Perusahaan Daerah Air Minum (PDAM) Kota Surakarta.

Hasil penelitian ini didukung oleh penelitian dari (Wijayanto \& Dotulong, 2017) menunjukkan bahwa motivasi berpengaruh positif terhadap kinerja karyawan pada PT. Multi Krindo. Sejalan dengan penelitian yang dilakukan oleh (Mubarok, 2018) yang menyatakan bahwa jika motivasi berprestasi berkembang dengan baik, itu akan meningkatkan kepercayaan diri pada kemampuan individu sehingga kinerja karyawan akan lebih baik. 


\section{PENUTUP}

Dapat disimpulkan bahwa kompetensi terutama kemampuan individu karyawan sangat dibutuhkan untuk meningkatkan kinerja karyawan Perusahaan Daerah Air Minum (PDAM) Kota Surakarta. Pelatihan yang diterapkan tidak mampu meningkatkan kinerja karyawan hal ini dikarenakan pelatihan yang diterapkan berupa seminar dan tidak memaksimalkan praktikum sehingga kurangnya pendampingan karyawan dalam penyelesaian pekerjaan secara langsung, serta hal lainnya yang mempengaruhi yaitu kurangnya pemerataan pelatihan karena kesenjangan pendidikan yang tinggi antara karyawan lapangan dengan karyawan kantor Perusahaan Daerah Air Minum (PDAM) Kota Surakarta. Motivasi yang diberikan perusahaan berupa tunjangan, insentif, reward, serta motivasi non material berupa pengangkatan jabatan bagi karyawan berprestasi, mampu mendorong dan mempengaruhi motivasi dalam diri karyawan untuk memajukan Perusahaan Daerah Air Minum (PDAM) Kota Surakarta.

Dalam penelitian skripsi ini penulis hanya membahas 3 variabel yang dijadikan faktor kinerja karyawan. Sehingga untuk penelitian selanjutnya diharapkan faktor-faktor yang mempengaruhi kinerja karyawan untuk dikembangkan lebih baik lagi. Penelitian skripsi terbatas hanya yang bekerja di Perusahaan Daerah Air Minum (PDAM) Kota Surakarta, diharapkan bisa menambah lebih luas lagi. Peneliti selanjutnya diharapkan meneliti pada objek yang berbeda. Selain itu, dapat memberikan gambaran yang lebih luas mengenai kinerja karyawan. 


\section{DAFTAR PUSTAKA}

Amstrong, M., \& Baron. (1998). erfect Management. Institute of Personal and Development. London.

Boulter, N., M. Dalziel., \& Hill, J. (1996). People and Competencies. London: Bidlles, Ltd.

Carter, L., \& Gray, D. M. (2011). The Relationship between Interpersonal Relational Competence and Employee Performance: A Developmental Model, 6 (3). https://doi.org/10.18848/1833-1882/CGP/v06i03/52029

Dessler, G. (2010). ManajemenSumber Daya Manusia (Edisi Kese). Jakarta: PT. Indeks.

Dewi, R. S., \& Ariyanto, E. (2016). Pengaruh Pelatihan, Kompetensi, dan Motivasi Terhadap Kinerja Karyawan, Telaah Bisnis, 17 (2): 113-130.

Dewi, A.A.I.S., and Darma, G.S. (2017). Proses Rekrutmen, Seleksi, Pelatihan, Penempatan dan Kinerja Karyawan, Jurnal Manajemen \& Bisnis, 14 (1): 1-18.

Ermiyanto, A. (2017). Analisis faktor motivasi intrinsik dan motivasi ekstrinsik pengaruhnya terhadap kinerja karyawan, VII (1): 18-30.

Ghozali, I. (2013). Aplikasi Analisis Multivariate Dengan Program IBM SPSS 21 (7th ed.). Semarang: Badan Penerbit Universitas Diponegoro.

Handoko, T. H. D. (2014). Manajemen Personalia dan Sumberdaya Manusia (Edisi Ketu). Yogyakarta: BPFE.

Hasibuan. (2014). Manajemen Sumber Daya Manusia. Bandung: Bumi Aksara.

Hok, T. T., Hubeis, A. V. S., \& Kuswanto, S. (2014). Pengaruh Pelatihan, dan Motivasi Terhadap Kinerja Karyawan, Sosiohumaniora, 16 (2): 215-221.

Hutapea, P., \& Thoha. (2008). Kompetensi Plus. Jakarta: Gramedia Pustaka Utama.

Iqbal, A., \& Asrar-ul-haq, M. (2018). International Journal of Production Economics Establishing relationship between TQM practices and employee performance, Journal of Production Economics, 203: 62-68.

Kartika, L. N., \& Sugiarto, A. (2014). Pengaruh Tingkat Kompetensi terhadap Kinerja Pegawai, XVII (1): 73-90.

Kasadirman. (2012). Manajemen Pengembangan Sumber Daya Manusia. Jakarta: Raja Grafindo Persada.

Kasmir. (2015). Manajemen Sumber Daya Manusia (Teori dan Praktik). Depok: PT. Rajagrafindo Persada.

Kasmir. (2016). Manajemen Sumber Daya Manusia (Teori dan Praktik). Depok: Raja Grafindo Persada.

Kaswan. (2011). Manajemen Sumber Daya Manusia untuk Keunggulan Bersaing Organisasi. 
Yogyakarta: Graha Ilmu.

Kusuma, G. C., Musadieq, M. Al, \& Nurtjahjono, G. E. (2015). Pengaruh motivasi dan pelatihan terhadap kinerja, Administrasi Bisnis, 21 (1): 1-7.

Landa, E. (2018). Influence of Training on Employees Performance in Public Institution in Tanzania, 8(2): 324-336. https://doi.org/10.5296/ijhrs.v8i2.13136

Mangkunegara, A. P. (2013). Manajemen Sumber Daya Manusia Perusahaan. Bandung: PT Remaja Rosdakarya.

Marwansyah. (2012). Manajemen Sumber Daya Manusia. Bandung: Alfabet.

Moeheriono. (2012). Pengukuran Kinerja Berbasis Kompetensi. Jakarta: Grafindo Persada.

Mondy, R. W. (2008). Human Resource Management. (M. M. Bayu Airlangga, Ed.) (Edisi Kese). Jakarta: PT Gelora Aksara Pratama.

Morgan, C. . (1986). Introduction to Psychology. Singapore: McGraw-Hill.

Mubarok, E. S. (2018). The Influence of Training, Competence, and Motivation on Employees Performance of Workers Social Security Agency in Banten Province, Indonesia, 9 (4): $129-139$.

Notoatmodjo, S. (2014). Pengembangan Sumber Daya Manusia. Jakarta: PT. Rinika Cipta.

Putra, F. T. (2016). Pengaruh Pelatihan dan Kompetensi terhadap Kinerja Karyawan, 4 (3).

Purnantara, I.M.H., and Darma, G.S. (2015). Competency, Organizational Health, Job Career, Job Performance And Employees Turnover, Jurnal Manajemen \& Bisnis, 12 (2): 90124.

Prihartanta, W. (2015). Teori Motivasi, Jurnal Adabiya, 1 (83); 1-11.

Riniwati, H. (2011). Mendongkrak Motivasi dan Kinerja: Pendekatan Pemberdayaan SDM. Jakarta: UB.

Robbins, S. P. (1998). Organizational Behavior. USA: Prentice Hal.

Sanches. (1997). Competence-Based Strategic Management. London: John William \& Sons.

Siagian, S. (2010). Manajemen Sumber Daya Manusia. Jakarta: PT. Bumi Aksara.

Sugiyono. (2012). Metode Penelitian Kuantitatif, Kualitatif dan R\&D. Bandung: Alfabet.

Triasmoko, D., Eko, N.G., \& Mukzam, M.D. (2014). Pengaruh Pelatihan Kerja terhadap Kinerja Karyawan, Administrasi Bisnis, 12 (1).

Veithzal, R (2013). Manajemen Sumber Daya Manusia untuk Perusahaan. Jakarta: PT. Rajagrafindo Persada.

Wakano, N., Pattiselanno, A. E., \& Kaplale. (2013). Hubungan Kompetensi Sumber Daya Manusia terhadap Kinerja Karyawan, Agrabisnis Kepulauan, 1 (3). 
Widiari, I.A.R., and Darma, G.S. (2017). Evaluasi Kinerja Pegawai Kontrak Melalui Tujuh Kompetensi Spencer Pada Pelayanan Denpasar Sewerage Development Project (DSDP), Jurnal Ilmiah Manajemen \& Bisnis, 2 (2): 360-367.

Widiatmika, P.H., and Darma, G.S. (2018). Good Corporate Governance, Job Motivation, Organization Culture Which Impact Company Financial Performance, Jurnal Manajemen \& Bisnis, 15 (3): 82-99.

Werner, T., \& Weckenmann, A. (2012). Sustainable quality assurance by assuring competence of employees. $\quad$ Measurement, $45 \quad$ (6): 1534-1539. https://doi.org/10.1016/j.measurement.2012.02.025

Wijayanto, J., \& Dotulong, L.O.H. (2017). Pengaruh Pelatihan, Kompetensi, dan Motivas Terhadap Kinerja Karyawan, Jurnal EMBA, 5 (2): 3048-3057.

Yao, Y., Liu, G. G., \& Cui, Y. (2019). On The Job Training and Organizational Performance, China Economic Review. Retrieved from https://doi.org/10.1016/j.chieco.2019.101396

Yuliana. (2017). Pengaruh Kompetensi dan Motivasi Kerja terhadap Kinerja Karyawan. Ilmiah Manajemen Bisnis, 17 (2): 135-150. 